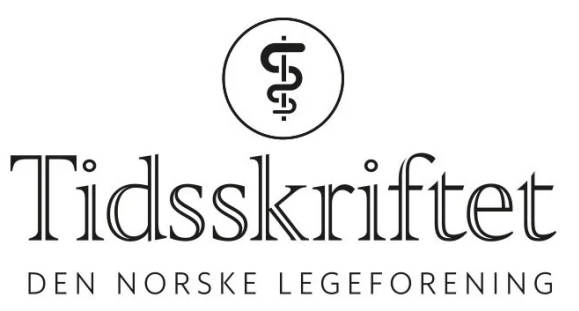

\title{
Covid-19: Italiensk leksjon
}

REDAKSJONELL KOMMENTAR

\section{KARI TVEITO}

Kari.tveito@tidsskriftet.no

Kari Tveito er lege, ph.d. og medisinsk redaktør i Tidsskriftet.

Forfatteren har fylt ut ICMJE-skjemaet og oppgir ingen interessekonflikter.

Mens våre italienske kollegaer står midt i en nasjonal helsekrise, tar de seg tid til å gi gode råd til helsepersonell i andre land. Dem bør vi følge. 


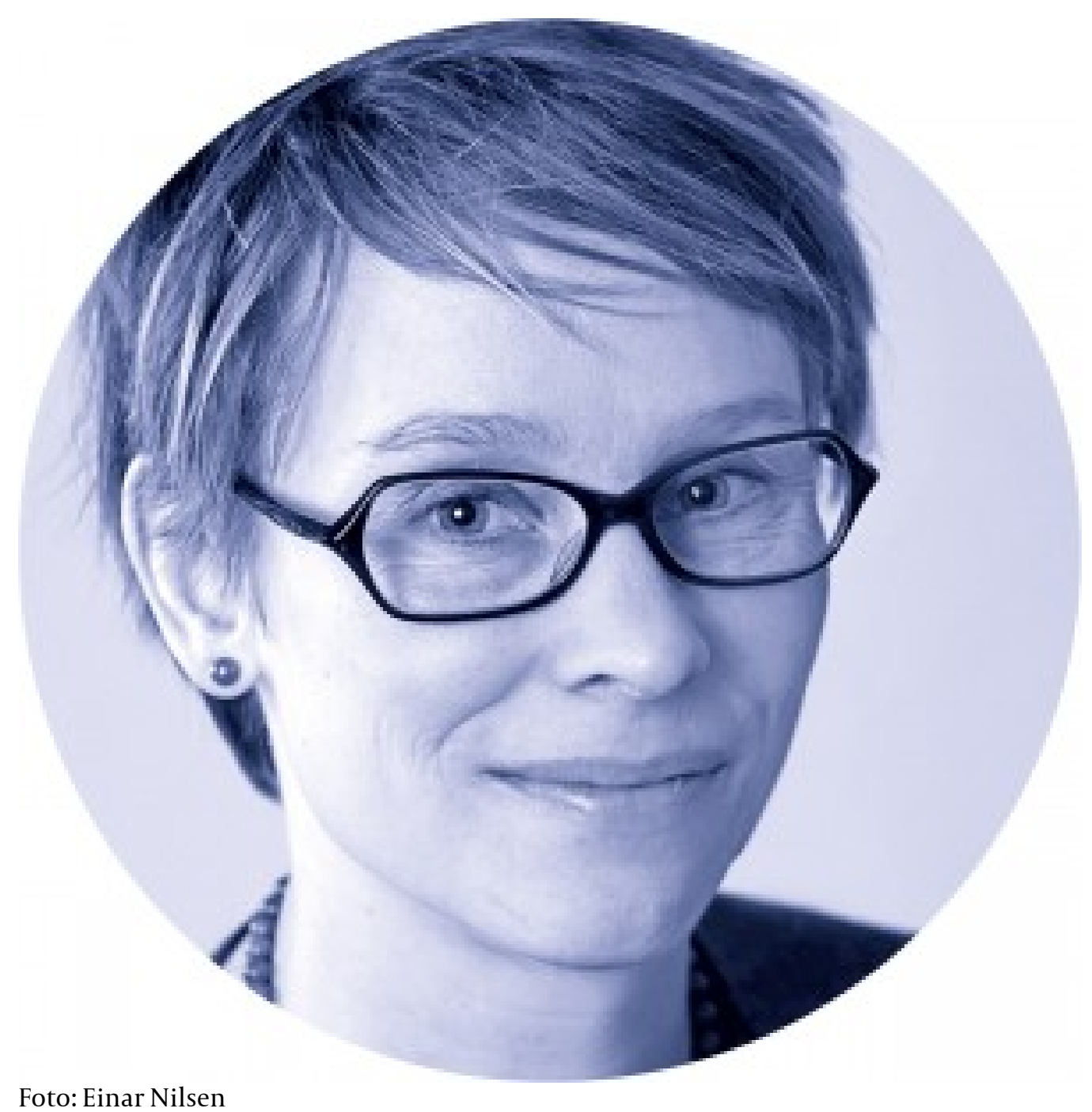

Søndag 8. mars bestemte italienske myndigheter seg for å sperre av flere områder i NordItalia. Dagen etter meldte regjeringen at hele landet var satt i karantene. De drastiske tiltakene var et desperat fors $ø \mathrm{k}$ på å få kontroll over koronavirus-epidemien (covid-19) som har rammet landet så hardt. Per 11. mars er 10149 smittet og 631 døde, og tallene stiger raskt (1).

I Lombardia, den folkerikeste regionen i Nord-Italia med Milano som hovedstad, er det flere smittede enn noe annet sted i Italia. På intensivavdelingene alene ligger det omkring 500 covid-19-pasienter (2 2 . Til tross for at Nord-Italia har et svært velutbygd helsevesen, har dette ført sykehusene til kanten av stupet. Det meldes om mangel på personell - fra leger til sykepleiere, ambulansesjåfører og renholdsarbeidere - og om mangel på utstyr. Fremfor alt har ikke sykehusene nok intensivplasser og respiratorer, og flere medier melder om svært vanskelige prioriteringer når leger må velge ut hvem de skal behandle og hvem de ikke skal behandle (2).

\section{Bli oppdatert: Tidslinje over koronavirus-utbruddet}

Heldigvis er det et godt stykke fra scenarioet som italienske leger beskriver, til dagens situasjon i Norge. Men også her hjemme kan sykehusene, og spesielt intensivavdelingene, komme til å bli stilt overfor en utfordring av de sjeldne. Hvordan skal vi nå forberede oss?

Denne uken fasiliterte Helsedirektoratet et nettseminar for norsk intensivpersonell om covid-19-epidemien (3). Blant foredragsholderne var Giacomo Grasselli, som er overlege ved et universitetssykehus i Milano. I direkteoverføringen fra Italia fikk tilhørerne høre hvordan sykehusene i Lombardia hadde samarbeidet siden krisen brøt ut 21. februar. Ifølge Grasselli trenger $12 \%$ av de innlagte pasientene intensivbehandling, og $88 \%$ av disse må legges på respirator. For å øke antallet intensivplasser har hele regionen lagt om 
sykehusdriften. Alle små og store sykehus, om lag $100 \mathrm{i}$ tallet, har laget egne enheter for covid-19-smittede. Elektive operasjoner er avlyst, og avdelinger og operasjonsstuer som vanligvis brukes til andre formål, benyttes til behandling av covid-19-pasienter. Det er også opprettet et nettverk mellom sykehusene for å koordinere og organisere arbeidet og fordele pasienter sykehusene imellom. Mange frivillige har trådt til, og pensjonerte helsearbeidere er tilbake i arbeid.

En slik direkte utveksling av informasjon, erfaringer og kunnskap mellom kollegaer over landegrensene som vi ble vitne til på mandag, er uhyre viktig. Vi skylder italienske leger stor takk for at de midt i en kaotisk situasjon passer på å advare og informere europeiske kollegaer mens det ennå er tid. For, som Preben Aavitsland fra Folkehelseinstituttet fortalte i samme seminar, kan en epidemi inndeles i fire faser. I fase 1 forekommer enkelttilfeller av smitte og vi kan spore smittekildene. I fase 2 dukker det opp nye smittekilder og klynger av smittede. I fase 3 begynner epidemien og det oppstår flere lokale utbrudd uten at man kan vite hvor smitten kommer fra. Fase 4 innebærer at epidemien er i full gang og passerer toppen i antall smittetilfeller.

«Det viktigste budskapet fra Italia er at kampen mot koronavirus bare kan vinnes ved strenge restriktive tiltak på samfunnsnivå»

Italia, som har det høyeste antall smittede per 100 ooo innbyggere i verden (11), befinner seg i fase 3 og 4 . I Norge befant vi oss frem til 10. mars fortsatt i den første fasen. Da kom meldingen om at det er oppdaget tilfeller av smitte uten kjent smittekilde, noe som kan bety på at vi er i ferd med å bevege oss over i fase 2. Fortsatt har vi et tidsvindu hvor vi kan lære av andre land, øke beredskapen på sykehusene våre, gjøre det logistiske arbeidet som trengs for å kunne behandle et stort antall smittede pasienter, fylle opp lagrene av smittevernutstyr og forberede helsepersonell på hva som kan skje. Men tiden er knapp.

Les også: Hvordan informere uten å skape unødig engstelse?

Det viktigste budskapet fra Italia er at kampen mot koronavirus bare kan vinnes ved strenge restriktive tiltak på samfunnsnivå. Ingen europeiske helsevesen har kapasitet til å ta seg av tusenvis av ekstra pasienter på en gang, når en stor andel trenger respiratorer og intensivbehandling. Vi må alle fortsette å vaske hendene - for oss selv, våre nærmeste, de som er spesielt utsatt ved sykdom og i solidaritet med våre kollegaer som skal stå i front hvis utbruddet utvikler seg videre. Skulle det bli nødvendig med strengere tiltak og begrensninger på vårt daglige liv, hvilket sannsynligvis vil skje, må vi tåle det.

Covid-19-epidemien vil ikke la seg stoppe uten samarbeid over landegrensene. At italienske leger tar seg tid til å snakke med kollegaer i andre land, er et eksempel til etterfølgelse for denne og fremtidige kriser. Det minner oss om at alle land nå må stå sammen, støtte hverandre og gjøre det vi kan for å hindre ytterligere spredning i og mellom landene

Call for papers: Tidsskriftet ønsker bidrag om covid-19

\section{LITTERATUR}

1. Johns Hopkins Coronavirus Resource Center. https://coronavirus.jhu.edu/map.html Lest 11.3.2020.

2. Aarnes H, Sætran F, Ask AO. Lege i Italia:- Vi må velge hvem vi skal behandle, og hvem vi ikke skal behandle. Det er som i en krig. Aftenposten 9.3.2020.

https://www.aftenposten.no/verden/i/rAJdp8/lege-i-italia-vi-maa-velge-hvem-vi-skal-behandle-oghvem-vi-ikke-skal-behandle-det-er-som-i-en-krig Lest 11.3.2020.

3. Helsedirektoratet. Webinar for norsk intensivpersonell om covid-19 epidemien. https://www.helsedirektoratet.no/nyheter/mote-for-norsk-intensivpersonell-om-covid-19-epidemien Lest 11.3.2020. 
Publisert: 11. mars 2020. Tidsskr Nor Legeforen. DOI: 10.4045/tidsskr.20.0210

(C) Tidsskrift for Den norske legeforening 2023. Lastet ned fra tidsskriftet.no 26. april 2023. 